Quarterly

ISSN $1898-2255$

Vol. 14, No. $1 / 2015$

http://www.ekonomia.i.prawo.umk.pl

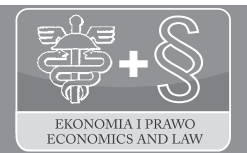

Article details:

Received: 25.09 .2013

Revised: 23.10 .2014

Accepted: 03.11.2014

Świadek A. Supply chains for innovation activity in regional industrial systems in Poland - some evidence from empirical research, „Ekonomia i Prawo. Economics and Law.”, Polszakiewicz B., Boehlke J. (ed.), Vol. 14, No. 1/2015, pp. 47-60. DOI: http://dx.doi.org/10.12775/ EiP.2015.004.

\title{
SUPPLY CHAINS FOR INNOVATION ACTIVITY IN REGIONAL INDUSTRIAL SYSTEMS IN POLAND - SOME EVIDENCE FROM EMPIRICAL RESEARCH
}

\author{
SUMMARY
}

Space and relations with suppliers and customers are significant determinants of innovativeness in industry not only in Poland, but also in much more developed countries. In industrial systems at their early phases of development, high tech solutions are usually owned by a relatively small number of enterprises, usually foreign ones. It affects the slow and limited diffusion of knowledge in regions without connection to an international chains of knowledge flow. In a such cases enclaves of innovation usually have a one-sided rather than system character based on the synergy of events. This research study has proved that described conditions are important for innovation activity in every regional industrial system, therefore these factors should be considered in innovative strategies.

Keywords: innovation, space, relation, customer, supplier, industry, region

JEL Classification: L52, O18, O31, R12, R39, R58

* Arkadiusz Świadek, University of Zielona Góra, Faculty of Economics and Management, Division of Innovation and Entrepreneurship, ul. Podgórna 50, 65-246 Zielona Góra, phone: +48 505075 319, e-mail: a.swiadek@wez.uz.zgora.pl. 


\section{INTRODUCTION}

The dynamics and system character of innovation so far have been described in theoretical approaches within evolutionary or Neo-Schumpeterian economics ${ }^{1}$. An innovation process on the level of a single enterprise is perceived in those concepts as a system of activities which are related by means of feedback, whereas innovation is a result of an interactive learning process which usually involves several actors from within and beyond the enterprise ${ }^{2}$.

Innovation and its diffusion become a result of an interactive and collective network process of personal and institutional changes evolving over time $^{3}$. They respond to the challenges of the "new economy" in the region: globalisation and acceleration of technological progress, thus creating an opportunity for economic development in less-developed regions ${ }^{4}$.

Innovation systems have become the subject-matter of numerous theoretical and empirical studies over the last 15-20 years. This approach is focused on the determinants of the development and diffusion of process and product innovations ${ }^{5}$. Its essence is the relationship between the internal and external players in the region ${ }^{6}$. The findings provide evidence that manufacturing enterprises are more successful if they are the elements of an integrated intensive network.

The operation of systems is based on interactions between individual participants of the network. Those relationships can be of either vertical, rather than horizontal character. Due to the complex character of the subject-matter, this paper concentrates only on the input-output relationships, i.e. relations with suppliers and customers of products manufactured by an industrial system.

1 A. Świadek, K. Szopik-Depczyńska, Koniunktura a aktywnośc innowacyjna systemów przemystowych w regionach Polski - modelowanie probitowe, „Barometr Regionalny”, Vol. 3(25)/2011, p. 95 .

${ }^{2}$ B.A. Lundvall (ed.), National Systems of Innovation: Towards a Theory of Innovation and Interactive Learning, Pinter, London 1992, p. 18.

3 A. Świadek, K. Szopik-Depczyńska, op. cit., p. 95.

${ }^{4}$ A Świadek, Determinanty aktywności innowacyjnej w regionalnych systemach przemystowych w Polsce, Wydawnictwo Naukowe Uniwersytetu Szczecińskiego, Szczecin 2008, p. 22.

${ }^{5}$ Ch. Edquist, M. McKelvey M. Introduction, [in:] Ch. Edquist M. McKelvey (eds), Systems of Innovation: Growth, Competitiveness and Employment, Edward Elgar, Chelten-ham 2000, p. 7.

${ }^{6}$ R. Sternberg, Innovation Networks and Regional Development - Evidence from the European Regional Innovation Survey (ERIS): Theoretical Concepts, Methodological Approach, Empirical Basis and Introduction to the Theme Issue, „European Planning Studies”, Vol. 8(4)/2000, p. 389-407. 
Modern regional networks aim at diversification of relationships through initiation of interactions with various groups of customers. In a traditional environment those relationships should focus on specialised interactions. It seems interesting to identify whether innovative performance of regional systems in Poland is determined by diverse or by narrow interactions, based on strong and lasting or weak interpersonal relationships, the distance between partners being close or far.

The conceptual framework outlined above has inspired the author to address the problem of the impact of enterprises on innovativeness of regional industrial systems. The major hypothesis of the study argues that innovative mechanisms inherent in territorial industrial systems and their relationships with the environment are significantly determined by the character of relationships among enterprises. They include: suppliers and customer, their localisation and character of the relationship. Those factors determine the present form of industrial systems in Poland. An appropriate identification of the course and constraints of the innovation process in the national system of economising is a basis for the construction of diversified development paths for innovation networks, allowing for the national and regional features and accelerating the processes of creation, absorption and diffusion of technology.

The major objective of the research was to attempt to find the variable determinants of the impact of the character of relationships among enterprises on their innovative performance within regional industrial systems and hence to define the constraints for a model regional structure of innovation network tailored to the needs of Poland and its regions. The research results presented in this study represent only a selection of findings.

From the viewpoint of sampling, the author decided to analyse the cases of three regions representing different levels of industrial development (strong, medium, weak), and different territorial systems (agglomerations, intermediate territories, provinces). Such a solution allowed a more in-depth analysis of the features characteristic of regional industrial systems in Poland and their evolution while significantly reducing the costs of such an extensive research project. Despite all the common attributes, however, the unique character of each case was not neglected.

The research was based on a questionnaire distributed among 1.152 enterprises. The basic method to acquire this amount of data involved an initial phone interview followed by sending the actual questionnaire by e-mail. 


\section{METHODOLOGICAL CONDITIONS OF THE RESEARCH - PROBIT MODELLING}

The methodological part of the analyses is based on the probability calculus. When a dependent variable takes dichotomous values, the possibilities of using the popular multiple regression, widely used for quantitative phenomena, are limited. The problem can be solved by an alternative solution - the logistic regression ${ }^{7}$. Its advantage is that an analysis and interpretation of results are similar to the classical regression method, hence the methods of selecting variables and testing the hypotheses have a similar pattern. There are, however, also differences, which include: more complex and time-consuming calculations and producing the residual plots usually do not contribute significantly to the model ${ }^{8}$. In a model where the dependent variable can equal either 0 or 1 , the expected value of the dependent variable may be interpreted as a conditional probability of an event at given independent values?

The forerunners in using the logistic curve were P.F. Verhulst and R.F. Pearl. A full model was not used, however, until 1994 and 1953 by J. Berkson ${ }^{10}$.

Generally, the logistic regression is a mathematical model which can be employed to explain the impact of several variables $X_{1}, X_{2}, \ldots, X_{k}$ on a dichotomous variable $Y$. If all the independent variables are qualitative, the logistic regression model is equivalent to a log-linear model. To describe such a phenomenon one could also employ the probit regression ${ }^{11}$.

The likelihood function for a logit or probit model is maximised by means of the techniques used for non-linear estimation. There are several user-friendly software tools available for logit or probit analysis.

Considering the fact that the variables are binary (i.e. they take two values -0 or 1 ), the majority of the results will be presented at the level of the structural form of the model. A "plus" sign preceding a parameter denotes that the probability of an innovative phenomenon in the selected group of entities is higher than for the rest of the population. Probit modelling is an effi-

7 A. Frenkel, Can regional policy affect firm's innovation potential in lagging regions?, „The Annals of Regional Science”, Vol. 34/2000, p. 315-341.

8 A. Stanisz, Przystępny kurs statystki, Vol. 2, Statsoft, Kraków 2007, p. 217.

9 A. Świadek, K. Szopik-Depczyńska, op. cit., p. 97-98.

${ }^{10} \mathrm{~J}$. Berkson, Application of the logistic function to bio-assay, "Journal of American Statistic Association", Vol. 39/1944, p. 357-65.

${ }^{11}$ M. Gruszczyński, S. Kluza, D. Winek, Ekonometria, WSHiFM, Warszawa 2003, p. 167. 
cient research tool in the case of big yet static samples where the dependent variable is qualitative ${ }^{12}$.

Each questionnaire was entered to the Excel spreadsheet for initial processing based on formal logic. The actual calculations were made with the Statistica software.

\section{SPACE, RELATIONS AND INNOVATIVE ACTIVITY IN PERIPHERIAL REGION (PODLASKIE CASE)}

In the first questionnaire distributed among enterprises in Podlaskie Region in 2008 and concerning the years 2005-2007, responses were received from 190 enterprises representing the processing industry (D section according to the Polish Classification of Activities).

Table 1. Probit models for independent variables "distance to supplier" and "relations with supplier" in describing innovativeness of industry in the Podlaskie Region (only models with statistical significance).

\begin{tabular}{|c|c|c|c|c|}
\hline \multirow[b]{2}{*}{ INNOVATIVE FEATURE } & \multicolumn{2}{|c|}{ DISTANCE TO SUPPLIER } & \multicolumn{2}{|c|}{ RELATIONS WITH SUPPLIER } \\
\hline & LOCAL & $\begin{array}{l}\text { BEYOND } \\
\text { REGION }\end{array}$ & TYPICAL & CLOSE \\
\hline$R \& D$ expenditure & $-, 58 x-0,31$ & $+, 38 x-0,56$ & & $+, 50 x-0,76$ \\
\hline Investment in new fixed assets (of which): & $-, 65 x-1,06$ & & & \\
\hline a) buildings, premises and land & & & $-, 72 x-0,43$ & $+, 65 x-1,04$ \\
\hline b) technical equipment and machinery & $-, 60 x+0,83$ & & & \\
\hline Computer software & & $+, 40 x+0,08$ & $-, 80 x+0,41$ & $+, 88 x-0,38$ \\
\hline \multicolumn{5}{|l|}{ Launching new products } \\
\hline $\begin{array}{l}\text { Implementation of new technological processes } \\
\text { (of which): }\end{array}$ & & $+, 52 x+0,36$ & $-, 64 x+0,70$ & $+, 61 x+0,14$ \\
\hline a) production methods & & $+, 39 x-0,15$ & & \\
\hline b) production-related systems & & & & $+, 48 x-0,76$ \\
\hline c) support systems & & $+, 84 x-0,72$ & $-, 74 x-0,54$ & $+, 50 x-1,04$ \\
\hline Cooperation with suppliers & & $+, 82 x-0,71$ & $-, 61 x-0,54$ & $+, 74 x-1,22$ \\
\hline \multicolumn{5}{|l|}{ Cooperation with competitors } \\
\hline Cooperation with PAS units & & & & \\
\hline
\end{tabular}

12 A. Świadek, K. Szopik-Depczyńska, op. cit., p. 98. 
Table 1 (Continued)

\begin{tabular}{|c|c|c|c|c|}
\hline \multirow[b]{2}{*}{ INNOVATIVE FEATURE } & \multicolumn{2}{|c|}{ DISTANCE TO SUPPLIER } & \multicolumn{2}{|c|}{ RELATIONS WITH SUPPLIER } \\
\hline & LOCAL & $\begin{array}{l}\text { BEYOND } \\
\text { REGION }\end{array}$ & TYPICAL & CLOSE \\
\hline Cooperation with universities & & & & \\
\hline Cooperation with domestic R\&D Units & & & & \\
\hline Cooperation with foreign R\&D Units & & & & \\
\hline Cooperation with customers & & & & \\
\hline Total cooperation in innovation & & & $-, 57 x+0,05$ & $+, 44 \mathrm{x}-0,38$ \\
\hline
\end{tabular}

Source: Own calculations based on questionaries' research evidence.

In the case of relations with suppliers, most of the areas of innovative activity is of significant importance. If an entity is in close contact with the supplier, then it implements innovative activities more frequently, whereas it is the opposite when relations with this group of companies are marginalized. Similarly as in other regions, though not as strong, high technological activity is connected with the performance of Podlaskie region industry within domestic and international supply chains.

An locally based supplier limits the efforts to finance new solutions. Considering the industrial weakness of the region and the number of local range relations, it is one of the basic structural and quantitative destimulants observed in the region. A low financial potential of enterprises in this region prevents dynamic development of new technologies. However, there are chances to relate to a large group of domestic suppliers, but based beyond the region, to accelerate innovative processes in the regional industrial system.

In the Podlaskie region, on the one hand, innovative activities in various forms will be undertaken the more frequently, the closer contacts there are with customers, on the other hand, customers shall be based beyond the region. However, in the case of the variable pertaining to relations, there is a small number of models with a statistically significant parameter (three), in two essential areas - implementation of new processes and innovative cooperation with suppliers. The latter is of particular value, since close contacts with customers affect the ability to create new knowledge in the contacts with suppliers, and thus in the chain of mutual interrelations. It can be observed that limiting contacts with customers to typical behaviours is unfavourable to implementation of innovative processes. The clearly visible dichotomy means that there is a clear polarization of customers' behaviour, similar to the relations with suppliers. A closely based customer de-stimulates undertaking in- 
novative processes. The situation is similar to this of suppliers, since the spatial and relationship factors catalyze their mutual interactions. In other words, the local environment as a potential customer of innovative goods remains unfriendly, similarly as in other regions.

Table 2. Probit models for independent variables "distance to customer" and "relations with customer" in describing innovativeness of industry in the Podlaskie Region (only models with statistical significance)

\begin{tabular}{|c|c|c|c|c|}
\hline \multirow[b]{2}{*}{ INNOVATIVE FEATURE } & \multicolumn{2}{|c|}{ DISTANCE TO CUSTOMER } & \multicolumn{2}{|c|}{ RELATIONS WITH CUSTOMER } \\
\hline & LOCAL & $\begin{array}{l}\text { BEYOND } \\
\text { REGION }\end{array}$ & $\begin{array}{c}\text { GOOD } \\
\text { NEIGHBOURS }\end{array}$ & CLOSE \\
\hline R\&D expenditure & $-, 80 x-0,19$ & & $-, 78 x-0,32$ & \\
\hline Investment in new fixed assets (of which): & $-, 54 x+1,11$ & & & \\
\hline a) buildings, premises and land & $-, 59 x-0,40$ & $+, 48 x-0,76$ & & \\
\hline b) technical equipment and machinery & $-, 52 x+0,89$ & & & \\
\hline Computer software & $-, 60 x+0,42$ & $+, 91 x+0,16$ & $-, 81 x+0,33$ & $+, 77 x-0,30$ \\
\hline \multicolumn{5}{|l|}{ Launching new products } \\
\hline $\begin{array}{l}\text { Implementation of new technological processes } \\
\text { (of which): }\end{array}$ & $-, 55 x+0,73$ & $1,20 x+0,47$ & & $+, 58 x+0,16$ \\
\hline a) production methods & $-, 54 x+0,17$ & & & \\
\hline b) production-related systems & & $+, 95 x-0,52$ & & \\
\hline c) support systems & & $+, 98 x-0,80$ & & \\
\hline Cooperation with suppliers & & & & $+, 54 x-1,06$ \\
\hline \multicolumn{5}{|l|}{ Cooperation with competitors } \\
\hline \multicolumn{5}{|l|}{ Cooperation with PAS units } \\
\hline \multicolumn{5}{|l|}{ Cooperation with universities } \\
\hline Cooperation with domestic R\&D Units & & $+, 90 x-1,61$ & & \\
\hline \multicolumn{5}{|l|}{ Cooperation with foreign R\&D Units } \\
\hline \multicolumn{5}{|l|}{ Cooperation with customers } \\
\hline Total cooperation in innovation & & & & \\
\hline
\end{tabular}

Source: Own calculations based on questionaries' research evidence.

The shape of an industrial system and its tendency for innovations is conditioned by its existence in industrial chains basing on international or domestic relations with suppliers and customers. The region has not acquired the internal capability to generate new technological solutions based on the 
absorption of knowledge, thus remaining dependant on international or domestic relations. The latter are rather scarce and this fact shall in future affect the rather endogenous and slow growth of technological potential. In the Podlaskie region there is still an imperative to act as an indirect link in the supply chain. Moreover, it is necessary to keep close relations with suppliers and customers in order to enable the process of knowledge transfer.

The regularities observed confirm that in the Podlaskie region industrial activity in the area of new products and technologies requires enterprises to overcome the barrier of distance (space) in order to enable knowledge transfer. The symptoms of change have not been observed as is the case in other industrially developed regions. The regional environment does not favour development of new solutions.

\section{SPACE, RELATIONS AND INNOVATIVE ACTIVITY IN A INTERMEDIATE REGION (WEST POMERANIA CASE)}

As far as the type of customers in West Pomerania (447 questionnaires) is concerned (research in 2011 for 2008-10 years), there are a variety of interactions representing innovative behaviours in the region.

The geographic factor (distance) becomes critical for innovative performance in industrial vertical relations. However, it takes a different direction from this pointed out in the literature. In West Pomerania, the shorter the distance from the main supplier, means the weaker innovative activity is. The necessary condition to stimulate introduction of new solutions is supply beyond the region. This follows from two reasons. The first one is a consequence of geographical location and the resulting considerable share of pro-export production. The other is connected with the weakness of the economic potential of the region. The models described herein suggest that in this region there are not too many enterprises which can supply to one another in similar areas. This means polarization of economy according to the "weak-strong" convention, thus proving operation of two industrial systems weakly related with each other. Relations in the plane of supply chains should have the character of close cooperation if a high level of innovativeness is expected. 
Table 3. Probit models for independent variables "distance to supplier" and "relations with supplier" in describing innovativeness of industry in West Pomerania (only models with statistical significance)

\begin{tabular}{|c|c|c|c|c|}
\hline \multirow[b]{2}{*}{ INNOVATIVE FEATURE } & \multicolumn{2}{|c|}{ DISTANCE TO SUPPLIER } & \multicolumn{2}{|c|}{ RELATIONS WITH SUPPLIER } \\
\hline & LOCAL & $\begin{array}{l}\text { BEYOND } \\
\text { REGION }\end{array}$ & TYPICAL & CLOSE \\
\hline$R \& D$ expenditure & $-, 34 x-0,29$ & - & $-, 38 x-0,31$ & $+, 35 x-0,62$ \\
\hline Investment in new fixed assets (of which): & - & - & $-, 79 x+0,99$ & $+, 52 x+0,49$ \\
\hline a) technical equipment and machinery & - & - & $-, 62 x+0,81$ & $+, 53 x+0,34$ \\
\hline Computer software & $-, 44 x+0,84$ & $+, 35 x+0,58$ & $-, 39 x+0,73$ & $+, 39 x+0,39$ \\
\hline $\begin{array}{l}\text { Implementation of new technological processes } \\
\text { (of which): }\end{array}$ & - & - & $-, 58 x+0,92$ & $+, 51 x+0,46$ \\
\hline a) production methods & & $-, 32 \times 0,19$ & $-, 50 x+0,16$ & $+, 30 x-0,13$ \\
\hline b) production-related systems & $-, 39 x-0,24$ & - & - & $+, 48 x-0,68$ \\
\hline c) support systems & $-, 34 x-0,18$ & $+, 55 x-0,47$ & - & - \\
\hline Cooperation with suppliers & - & & $-, 41 x-0,40$ & $+, 31 x-0,68$ \\
\hline Cooperation with competitors & - & $+, 40 x-1,66$ & - & - \\
\hline Cooperation with domestic R\&D Units & - & $+, 29 x-0,30$ & - & - \\
\hline Cooperation with customers & $-, 28 x-0,11$ & - & - & - \\
\hline Total cooperation in innovation & $-, 34 x-0,29$ & - & $-, 38 x-0,31$ & $+, 35 x-0,62$ \\
\hline
\end{tabular}

Source: Own calculations based on questionaries' research evidence.

Vertical relationships with customers clearly indicate that the relationship factor is more relevant than the spatial. Nonetheless, it should be stated that the number of statistical models is close to that generated for Podlaskie Region. An essential condition of encouraging appropriate activity within new products and technologies is a significant distance to customers although in such a case it needs to be accompanied by close cooperation along the production chain. It provides evidence supporting the previously formed thesis about the dichotomy of industrial systems in Poland and their close relationships with innovative interregional and even international networks. An internal industrial system, being weak, does not provide appropriate conditions for a dynamic development of regional interactions which become essential to improvement of innovative performance in the leading group of enterprises, forcing them to incur costs of covering the distance in order to acquire knowledge. Moreover, it should be observed that it requires more than good neighbour relations with the analysed groups of entities; typical (basic) re- 
lationships with customers are even more harmful (negative) to stimulation of innovative activity.

Table 4. Probit models for independent variables "distance to customer" and "relations with customer" in describing innovativeness of industry in the West Pomerania Region (only models with statistical significance)

\begin{tabular}{|l|c|c|c|c|}
\hline \multirow{2}{*}{ INNOVATIVE FEATURE } & \multicolumn{2}{c|}{ DISTANCE TO CUSTOMER } & \multicolumn{2}{c|}{ RELATIONS WITH CUSTOMER } \\
\cline { 2 - 5 } & LOCAL & FOREIGN & TYPICAL & CLOSE \\
\hline R\&D expenditure & - & - & - & $+, 57 x-0,81$ \\
\hline Investment in new fixed assets (of which): & - & - & $-, 51 x+0,92$ & - \\
\hline Computer software & & $+, 41 x+0,55$ & $-, 49 x+0,73$ & $+, 42 x+0,36$ \\
\hline $\begin{array}{l}\text { Implementation of new technological processes (of } \\
\text { which): }\end{array}$ & - & $+, 34 x+0,72$ & $-, 67 x+0,92$ & $+, 60 x+0,39$ \\
\hline a) production-related systems & - & - & $-, 46 x-0,27$ & $+, 54 x-0,74$ \\
\hline b) support systems & $-, 36 x-0,19$ & $+, 42 x-0,44$ & $-, 48 x-0,25$ & $+, 33 x-0,55$ \\
\hline Cooperation with suppliers & - & - & - & $+, 33 x-0,71$ \\
\hline Cooperation with PAS units & & $+, 39 x-1,54$ & - & $+, 78 x-2,05$ \\
\hline Cooperation with domestic R\&D Units & $-, 26 x-0,14$ & $+, 29 x-0,31$ & - & $+, 36 x-0,50$ \\
\hline Total cooperation in innovation & - & - & - & $+, 57 x-0,81$ \\
\hline
\end{tabular}

Source: Own calculations based on questionaries' research evidence.

It should be also observed that the development of an industrial system is accompanied by an increasing number of models describing the analysed phenomena, where the parameters are statistically significant. It is the evidence for a better transparency of innovative networks described by the selected variables. The role of those factors becomes more and more significant over time.

\section{SPACE, RELATIONS AND INNOVATIVE ACTIVITY IN WELL-DEVELOPED REGION (UPPER SILESIA CASE)}

When we analyse the character of the customer, it may be observed that industrial enterprises based in Upper Silesia (515 questionnaires) are elements of a strong industrial system but, again, provided that they are not the final link in the supply chain (research in 2013 for 2010-12 years).

Vertical "downwards" inter-industrial relations play an important role in developing innovative processes in the region. However, models which il- 
lustrate the impact of distance on the technological activity of industry are more frequent than those which refer to relations. A weakness of the internal industrial system is confirmed by the fact that the existence of a supplier based in the region does not stimulate development of new solutions. Only "providers" of technology from beyond the region are of special importance in stimulating innovative activity in the region; the exception being new manufacturing methods, which are more frequently introduced when the supplier is based in the region. May be this is one of the first symptoms of changing the significance of the "distance" variable in the direction of tendencies observed in developed countries.

Table 5. Probit models for independent variables "distance to supplier" and "relations with supplier" in describing innovativeness of industry in the Upper Silesia Region (only models with statistical significance)

\begin{tabular}{|c|c|c|c|c|}
\hline \multirow[b]{2}{*}{ INNOVATIVE FEATURE } & \multicolumn{2}{|c|}{ DISTANCE TO SUPPLIER } & \multicolumn{2}{|c|}{ RELATIONS WITH SUPPLIER } \\
\hline & LOCAL & $\begin{array}{l}\text { BEYOND } \\
\text { REGION }\end{array}$ & TYPICAL & CLOSE \\
\hline R\&D expenditure & $-, 34 x+0,02$ & $+, 33 x-0,20$ & $-, 40 x-0,01$ & $+, 40 x-0,37$ \\
\hline Investment in new fixed assets (of which): & $-, 45 x+1,01$ & $+, 35 x+0,81$ & $-, 41 x+1,01$ & $+, 28 x+0,73$ \\
\hline a) buildings, premises and land & $-, 24 x-0,24$ & $+, 35 x-0,44$ & $-, 34 x-0,26$ & - \\
\hline b) technical equipment and machinery & $-, 37 x+0,77$ & $+, 26 x+0,62$ & $-, 37 x+0,78$ & - \\
\hline Computer software & $-, 54 x+0,82$ & $+, 36 x+0,60$ & - & - \\
\hline Launching new products & - & $+, 26 x-0,88$ & - & - \\
\hline $\begin{array}{l}\text { Implementation of new technological processes (of } \\
\text { which): }\end{array}$ & $-, 35 x+0,92$ & - & - & - \\
\hline a) production methods & $+, 28+0,08$ & - & $-, 30 x+0,22$ & - \\
\hline b) production-related systems & $-, 32-0,27$ & $\begin{array}{l}+, 37 x-0,51 \\
+, 35 x-0,43\end{array}$ & - & - \\
\hline c) support systems & - & $+, 51 x-0,54$ & - & - \\
\hline Cooperation with suppliers & - & - & $-, 48 x-0,35$ & $+, 43 x-0,75$ \\
\hline Cooperation with universities & $-, 44 x-1,39$ & $+, 75 x-1,70$ & - & $+, 50 x-1,91$ \\
\hline Cooperation with foreign R\&D Units & $-, 83 x-1,70$ & $+, 75 x-2,08$ & - & - \\
\hline Cooperation with customers & & $+, 42 x-0,68$ & - & - \\
\hline Total cooperation in innovation & $-, 29 x+0,16$ & $+, 39 x+0,05$ & $-, 37 x+0,18$ & $+, 32 x-0,12$ \\
\hline
\end{tabular}

Source: Own calculations based on questionaries' research evidence.

Models describing interactions with suppliers, though not as common as in the case of the "distance" variable, indicate clearly the need of maintain- 
ing close contacts with suppliers, since, in contrast to lack of contacts, they dynamize innovative processes. Thus from the perspective of suppliers the regional environment is not favourable, as it does not advance (does not affect) the imperative to develop the available technologies.

In the third of the regions, again a rise in the number of significant statistical models describing the relevance of spatial factors and relationships is observed. Customers based outside the region stimulate innovative activities whereas those based nearby do not have a positive impact on those efforts. Weak diversification within the region indicates that there are no negative tendencies in that area observed in other regions and hence suggests that the regional environment evolves in the positive direction.

Table 6. Probit models for independent variables "distance to customer" and "relations with customer" in describing innovativeness of industry in the Upper Silesia Region (only models with statistical significance)

\begin{tabular}{|c|c|c|c|c|}
\hline \multirow[b]{2}{*}{ INNOVATIVE FEATURE } & \multicolumn{2}{|c|}{ DISTANCE TO CUSTOMER } & \multicolumn{2}{|c|}{ RELATIONS WITH CUSTOMER } \\
\hline & LOCAL & $\begin{array}{l}\text { BEYOND } \\
\text { REGION }\end{array}$ & TYPICAL & CLOSE \\
\hline R\&D expenditure & $-, 54 x+0,03$ & $+, 33 x-0,21$ & $-, 61 x-0,01$ & $+, 38 x-0,38$ \\
\hline Investment in new fixed assets (of which): & $-, 36 x+1,01$ & - & $-, 51 x+1,00$ & $+, 44 x+0,60$ \\
\hline a) buildings, premises and land & $-, 45 x-0,23$ & $+, 27 x-0,42$ & $-, 45 x-0,26$ & $+, 30 x-0,54$ \\
\hline b) technical equipment and machinery & - & - & $-, 45 x+0,77$ & $+, 37 x+0,42$ \\
\hline Computer software & $-, 41 x+0,81$ & - & $-, 46 x+0,78$ & $+, 33 x+0,47$ \\
\hline $\begin{array}{l}\text { Implementation of new technological processes (of } \\
\text { which): }\end{array}$ & $-, 41 x+0,95$ & $+, 44 x+0,80$ & $-, 48 x+0,92$ & $+, 48 x+0,49$ \\
\hline a) production methods & - & - & $-, 47 x+0,23$ & $+, 32 x-0,09$ \\
\hline b) support systems & - & - & $-, 36 x-0,40$ & - \\
\hline Cooperation with suppliers & - & - & $-, 38 x-0,38$ & - \\
\hline Cooperation with universities & - & - & - & $+, 71 x-2,11$ \\
\hline Cooperation with domestic R\&D Units & $-, 44 x-1,01$ & $+, 44 x-1,28$ & - & - \\
\hline Cooperation with customers & $-, 32 x-0,54$ & $+, 35 x-0,66$ & $-, 57 x-0,54$ & $+, 60 x-1,09$ \\
\hline Total cooperation in innovation & - & $+, 27 x+0,01$ & $-, 46 x+0,17$ & $+, 37 x-0,17$ \\
\hline
\end{tabular}

Source: Own calculations based on questionaries' research evidence.

Having minimal contacts with customers has a negative impact on innovative activity in Silesian industry. It is contrasted again with the need of maintaining close relationships. Such a situation is an imperative to 
strengthen industrial relationships as an essential element of innovative processes which usually go beyond not only enterprises but also the region they concern.

The observed regularities prove once again that the activity of Silesian industry within new products and technologies requires enterprises to overcome the distance (space) barrier to enable the transfer of knowledge. There are, however, symptoms of change, as the regional environment becomes more and more often supportive of development of new solutions.

\section{CONCLUSIONS}

The three regional industrial systems in Poland analysed in this study reveal an evolution in the approach to innovative activities, considering suppliers' and customers' localisation or relationships with them. There are also convergences between those systems which suggest that the tendencies observed for the most developed cases are not similar for Poland.

Generation and diffusion of knowledge in Polish regions is determined by their relationships with international industry networks as they form the major channel of the transfer of technology which helps to reduce the gap between Poland and other countries. Intraregional relationships are too weak to initiate innovative processes yet with the evolution of the economic system, they acquire this ability.

Unlike enterprises in technologically developed countries where innovative activities are focused in regional systems, Polish enterprises are forced to overcome the distance barrier. Nevertheless, it seems a natural direction for new knowledge which affects the development of national industrial systems. It is also noteworthy that in the strongest case, the regional environment is no longer a destimulant in innovative activities.

Enterprises which are the final link of the production chain are less innovative than those producing for industry. It is an indication of a low technological level of solutions offered and a still insufficient demand pressure which would drive innovation. Regional systems have not yet become mature enough in terms of competitiveness to participate in the dynamic changes based on the technological factor in the international market.

Along with the growing economic potential of Polish regions, there is stronger and stronger diversification of entities following an innovative path. The relevance of close long-term relationships with suppliers and customers becomes more and more relevant thus raising mutual trust and enabling involvement in more risky areas of business. It follows that innovative 
activity is determined by the existence of repetitive, long-term yet typical interactions, which seems consistent with the results of the research carried out worldwide.

\section{BIBLIOGRAPHY}

Berkson J., Application of the logistic function to bio-assay, ,Journal of American Statistic Association", Vol. 39/1944, http://dx.doi.org/10.1080/01621459.1944.10500699. Edquist Ch., McKelvey M. Introduction, [in:] Ch. Edquist M. McKelvey (eds), Systems of Innovation: Growth, Competitiveness and Employment, Edward Elgar, Cheltenham 2000.

Frenkel A., Can regional policy affect firm's innovation potential in lagging regions?, „The Annals of Regional Science”, Vol. 34/2000, http://dx.doi.org/10.1007/ s001689900015.

Gruszczyński M., Kluza S., Winek D., Ekonometria, WSHiFM, Warszawa 2003.

Lundvall B.A. (ed.), National Systems of Innovation: Towards a Theory of Innovation and Interactive Learning, Pinter, London 1992, http://dx.doi. org/10.1080/08109029308629360.

Stanisz A., Przystępny kurs statystki, Vol. 2, Statsoft, Kraków 2007.

Sternberg R., Innovation Networks and Regional Development - Evidence from the European Regional Innovation Survey (ERIS): Theoretical Concepts, Methodological Approach, Empirical Basis and Introduction to the Theme Issue, „European Planning Studies", Vol. 8(4)/2000, http://dx.doi.org/10.1080/713666420.

Świadek A., Determinanty aktywności innowacyjnej w regionalnych systemach przemystowych w Polsce, Wydawnictwo Naukowe Uniwersytetu Szczecińskiego, Szczecin 2008.

Świadek A., Szopik-Depczyńska K., Koniunktura a aktywność innowacyjna systemów przemystowych w regionach Polski - modelowanie probitowe, „Barometr Regionalny", Vol. 3(25)/2011. 